\title{
Comparative Effects of Hydro-, Hormonal-, Osmotic-, and Redox- Priming on Seed Germination of Creeping Bentgrass under Optimal and Suboptimal Temperatures
}

\author{
Kun Jia, Michelle DaCosta, and J. Scott Ebdon \\ Stockbridge School of Agriculture, Paige Laboratory, University of \\ Massachusetts, Amherst, MA 01003
}

Additional index words. Agrostis stolonifera, seed emergence, seed lot, turfgrass

\begin{abstract}
Reseeding of creeping bentgrass (Agrostis stolonifera L.) under unfavorable temperature $\left(\approx 10^{\circ} \mathrm{C}\right)$ is a common practice on golf putting greens and fairways. Seed priming to enhance germination and early emergence increases seeding success. Seed priming comparing abscisic acid (ABA), gibberellic acid (GA), glycinebetaine (GB), hydrogen peroxide $\left(\mathrm{H}_{2} \mathrm{O}_{2}\right)$, and polyethylene glycol (PEG) has not been investigated in turfgrass. Our objective was to compare these chemical primers at three concentrations with water- and unprimed-seed at two competing germinating temperatures (10 vs. $25^{\circ} \mathrm{C}$ ). Two seed lots of ' $\mathrm{T}-1$ ' creeping bentgrass were compared. Curve fitting of daily germination was used to compute days to $50 \%$ germination $\left(D_{50}\right)$ and maximum germination percentage $\left(G_{\max }\right)$. Cold $\left(10^{\circ} \mathrm{C}\right)$ significantly inhibited emergence (higher $D_{50}$ ) more than $G_{\max }$. The effects of primers and their rates varied with the seed lot and temperature. Enhancement of seed germination measured as early emergence (lower $D_{50}$ ) and/or higher $G_{\max }$ were only detected at $10^{\circ} \mathrm{C}$. Osmotic primers (GB and PEG) were most effective in promoting germination relative to unprimed seed followed by hormone primers (ABA and GA) with redox primers $\left(\mathrm{H}_{2} \mathrm{O}_{2}\right)$ least effective. Glycinebetaine primed seed was the only primer effective at all concentrations, with the $100 \mathrm{~mm}$ concentration the only concentration to enhance germination by increasing both $\mathbf{G}_{\max }$ and early emergence (lower $D_{50}$ ) compared with unprimed seed.
\end{abstract}

Overseeding and reestablishment of damaged golf greens and fairways planted to creeping bentgrass (Agrostis stolonifera L.) is a common practice following injuries. Reseeding is a necessary and costly investment to promote recovery and to maintain adequate density and uniformity for play (Green et al., 2018). Adverse conditions such as cold soil temperatures $\left(\approx 10{ }^{\circ} \mathrm{C}\right)$ typical of early spring plantings in temperate areas of the northeastern United States can delay seed germination and diminish establishment vigor of cool-season grasses compared with more favorable soil temperatures of 20 to $30{ }^{\circ} \mathrm{C}$ (He et al., 2013; Liu et al., 2001; McGinnies, 1960; Wright et al., 1978). Delayed growth from slow to emerge turfgrass plants can reduce competition and therefore contribute to lower contributions of planted species in the turf stand (Larsen et al., 2004). In addition, a delay in the

Received for publication 9 Apr. 2020. Accepted for publication 10 June 2020.

Published online 6 August 2020.

J.S.E. is the corresponding author. E-mail: sebdon@ umass.edu.

This is an open access article distributed under the CC BY-NC-ND license (https://creativecommons. org/licenses/by-nc-nd/4.0/). germination may result in high susceptibility to stresses, such as drought (Young and Evans, 1982) and weeds (Murphy et al., 2005).

Seed priming is a preplant method of promoting partial germination before planting as seed. During seed priming (i.e., controlled soaking treatment), the emergence of the radicle is initiated, but the process is interrupted (inhibited) by drying of the seeds. In a recent review of priming agents in agricultural crops (Jisha et al. (2013), numerous primers, including water (hydropriming), hormonal, osmotic, matric, and redox primers, have been shown to enhance final germination percentages, reduce the time to germination, improve synchronization of germination, and increase the stress tolerance of seedlings following priming compared with unprimed seed. To that end, priming enhancement of germination may be achieved by either inducing physiological changes in the seed before germination as a pre-soaking or pre-conditioning treatment and/or after emergence as an exogenous application to the seedling plant. In priming of turfgrass seed, hydropriming with distilled water, osmotic-priming using GB (Pill and Necker, 2001; Zhang and Rue, 2012; Zhang et al., 2014) and PEG (Danneberger et al., 1992; Wang et al., 2014), matrix priming
(Yamamoto et al., 1997b), and redox priming using $\mathrm{H}_{2} \mathrm{O}_{2}$ (Wang et al., 2014) have been investigated with mixed results. To our knowledge, seed priming using hormones such as ABA and GA have not been investigated in turfgrass. Moreover, comparative studies of hydro-, hormone-, osmotic-, and redox-primers and their efficacy as primers has not been reported in turfgrass.

Previous research in agricultural crops has demonstrated the success of seed priming in eliciting beneficial response is specific to the priming agent, the rate or concentration of the primer, and the stress (Iqbal and Ashraf, 2005). In turfgrass seed priming studies conducted by Zhang et al. (2014), most of the six turfgrass species evaluated showed limited response to $\mathrm{GB}$ concentrations $(5,10$, and 50 $\mathrm{mM}$ ) in both their effect on daily germination and final germination percentages. The authors reported creeping bentgrass seed primed with the 5-mM concentration promoted higher daily germination rates (i.e., measure of the speed of germination) than unprimed seed while no effect was observed on final germination percentage. Alternatively, Zhang and Rue (2012) in a similar comparison of the same cool-season turfgrass species reported no difference in daily germination rates relative to unprimed seed with GB concentrations ranging from 50 to 200 mM. However, all rates of GB enhanced final germination percentage compared with unprimed seed. Zhang et al. (2014) concluded priming to ameliorate salinity, drought, and temperature stress is species and concentration (rate) specific.

In agronomic crops, the evaluation of priming agents and the effects of temperature have observed a greater enhancement of germination under suboptimal germination temperatures $\left(<15^{\circ} \mathrm{C}\right)$ (Bodsworth and Bewley, 1981; Hardegree, 1994; Heydecker et al., 1975; Knypl and Khan, 1981). Similarly in turfgrass priming studies the response to priming was more readily apparent under cool temperatures for both slow germinating kentucky bluegrass (Poa pratensis L.) (Yamamoto et al., 1997a) and quick to emerge perennial ryegrass (Lolium perenne L.) (Danneberger et al., 1992). In general, researchers have observed greater differences in germination characteristics due to priming under less favorable germinating temperatures (Danneberger et al., 1992; Pill, 1994; Yamamoto et al., 1997a).

Priming-induced tolerance has been investigated for various stresses; however, the efficiency of various priming agents such as hormones, hydropriming, osmotic, and redox priming has not been comparatively investigated. Creeping bentgrass is an economically important turf species to the golf industry, and the efficacy of the vast array of primers to stimulate early emergence at suboptimal germinating temperatures has not been investigated. Our specific objective was to compare various primers and their efficacy to enhance germination characteristics of creeping bentgrass under suboptimal germination temperatures. 


\section{Materials and Methods}

Seed priming and priming concentrations. A popular (commercially) available cultivar $\mathrm{T}-1$ creeping bentgrass seed, with parent germplasm originating from New England golf courses, was selected for germination tests. The following primers were evaluated including seed primed with water (double deionized), hormonal primers (ABA and GA), osmotic primers (GB and PEG 6000), and redox primer hydrogen peroxide $\left(\mathrm{H}_{2} \mathrm{O}_{2}\right)$. Three concentrations of each primer (except water-primed) were evaluated at low, medium, and high concentrations corresponding to $\mathrm{ABA}(0.05,0.1$, and $0.2 \mu \mathrm{M}$; Gao et al., 2002), GA $\left(100,200\right.$, and $\left.300 \mathrm{mg} \cdot \mathrm{L}^{-1}\right)$, GB (50, 100, and $150 \mathrm{~mm}$; Zhang and Rue, 2012), $\mathrm{H}_{2} \mathrm{O}_{2}(0.1,1$, and $100 \mathrm{~mm}$; Yadav et al., 2011), and PEG (100, 200, and $300 \mathrm{~g} \cdot \mathrm{L}^{-1}$; Murray, 1990). Concentrations were chosen based on previous research from selected studies allowing for a baseline to determine optimal concentrations for each primer. Seeds were surface sterilized using $95 \%$ ethanol for $2 \mathrm{~min}$ and $2 \%$ sodium hypochlorite solution for $10 \mathrm{~min}$, triple rinsed with distilled water and then air dried at room temperature for $24 \mathrm{~h}$. All priming treatments contained $1 \mathrm{~g}$ of seed to $1.5 \mathrm{~mL}$ of priming solution. Priming solutions with seed were placed in microtubes with tubes agitated constantly for $24 \mathrm{~h}$ to allow for optimal absorption. Seed was then air dried for at least $24 \mathrm{~h}$. Twenty-five seeds were placed on filter paper saturated with deionized water using $8-\mathrm{cm}$ diameter petri plates for each primer and concentration for a total of three petri plates as subsamples per primer concentration.

Temperature treatments. Two growth chambers were used with one chamber set to $25^{\circ} \mathrm{C}$ as optimal and a second chamber set to $10^{\circ} \mathrm{C}$ as the low temperature treatment for tests for creeping bentgrass under stressful conditions. Unprimed seed, water-primed seed along with all five primers and their three concentrations ( 17 treatments $\times 3$ subsamples $=51$ petri plates) were randomized within each of the two growth chambers at the two set temperatures. The process and randomization was repeated for a total of three replications which were blocked as timing variables. Temperature was analyzed as main plot with unprimed seeds, water-primed seeds, and primers and their corresponding concentrations as subplots. Relative humidity within each chamber fluctuated between $50 \%$ and $80 \%$. Petri plates with seeds were placed into the growth chambers under a 10 -h photoperiod with low light levels $(\approx 70$ PAR). Distilled water was applied to petri dishes as necessary to prevent filter paper and seeds from drying. The experiment was repeated as Expts. 1 and 2 using a different seed lot because the germination characteristics can vary with the seed lot of the same cultivar (Liu et al., 2001).

Data collection and analysis. Seed germination was defined as $2 \mathrm{~mm}$ emerged radical visible under $2 \times$ magnification.
Counts were made daily for $22 \mathrm{~d}$ at $10{ }^{\circ} \mathrm{C}$ and $10 \mathrm{~d}$ at $25^{\circ} \mathrm{C}$ until no further germination was observed. Daily germination data were analyzed by curve fitting using a fourparameter sigmoid model (Sigma Plot; SPSS, Chicago) where Y (i.e., germination percentage) and the independent variable $\mathrm{X}$ (i.e., days) were fitted to determine days to $50 \%$ germination $\left(\mathrm{D}_{50}\right.$, days $)$ for each replicate and each combination of priming treatment (primer and priming concentration) and temperature $\left(10\right.$ and $\left.25^{\circ} \mathrm{C}\right)$. Maximum germination percentage $\left(\mathrm{G}_{\max }, \%\right)$ was simultaneously determined by sigmoidal curve fitting. Curve fitting of the individual subsamples (petri plates) were averaged and then analyzed by analysis of variance (ANOVA) using MINITAB (State College, PA). Seed primers (i.e., unprimed, water primed, ABA, GA, GB, PEG, and Redox primers) and priming rates (i.e., linear and quadratic components for ABA, GA, GB, PEG, and Redox primers) main effect sum of squares (SS) were partitioned into a set of orthogonal single degree of freedom (df) contrast to test for differences between group means comparing various primers (6 df in all) and associated priming rates or concentrations (10 df in all). Hence, all $16 \mathrm{df}$ for main effect of primers and associated concentrations were partitioned. The six df for primers were partitioned as 1) Control (water primed + no water priming) vs. all other primers; 2) Water-priming vs. no priming; 3) Hormone (ABA + GA) vs. osmopriming (GB + PEG); 4) $\mathrm{ABA}$ vs. GA, 5) GB vs. PEG; and 6) $\mathrm{H}_{2} \mathrm{O}_{2}$ vs. $\mathrm{ABA}+\mathrm{GA}+\mathrm{GB}+\mathrm{PEG}$. The $10 \mathrm{df}$ for priming rates as linear $\left(_{\mathrm{L}}\right)$ and quadratic $(\mathrm{Q})$ components are reported as $\mathrm{ABA}_{\mathrm{L}}, \mathrm{ABA}_{\mathrm{Q}}$, $\mathrm{GA}_{\mathrm{L}}, \mathrm{GA}_{\mathrm{Q}}, \mathrm{GB}_{\mathrm{L}}, \mathrm{GB}_{\mathrm{Q}}, \mathrm{H}_{2} \mathrm{O}_{2 \mathrm{~L}}, \mathrm{H}_{2} \mathrm{O}_{2 \mathrm{Q}}$, and as $\mathrm{PEG}_{\mathrm{L}}$ and $\mathrm{PEG}_{\mathrm{Q}}$, respectively. The $16 \mathrm{df}$ orthogonal contrasts for main effects due to primers $(6 \mathrm{df})$ and associated concentrations $(10 \mathrm{df})$ were crossed with temperature (10 vs. $25^{\circ} \mathrm{C}$ ) to partition the $16 \mathrm{df}$ and associated SS for interaction to detect significant $(P \leq 0.10)$ departures from seed priming main effects caused by interaction with temperature. Priming + priming rate and temperature effects were crossed with Expt. (1 and 2, i.e., different seed lots) to determine interaction with seed lots. Fisher's protected least significant difference (LSD) values at the 0.05 level are reported in the text for various comparisons between treatment means. No departures from the assumptions of the ANOVA were detected in homogeneity of variance or departures from normality.

\section{Results and Discussion}

Significant interactions were observed for measured responses between experimental runs 1 and 2 (different seed lots of ' $\mathrm{T}-1$ ' creeping bentgrass) and associated treatment main effects of seed priming and priming rate and their interaction with temperature (10 vs. $25^{\circ} \mathrm{C}$ ). The results for days to $50 \%$ germination $\left(\mathrm{D}_{50}\right)$ and maximum germination percentage $\left(G_{\max }\right)$ are therefore reported by individual experimental runs (Expts. 1 and
2). Response to priming can vary, which is often attributed to variations in seed lot (Larsen and Bibby, 2004; Liu et al., 2001; Snapp et al., 2008).

Expt. 1: Temperature main effects on $D_{50}$. Temperature $\left(10\right.$ vs. $\left.25^{\circ} \mathrm{C}\right)$ main effect accounted for $\approx 79 \%$ of the total variation in seed priming treatment (priming + priming rate) and their interaction with temperature. Low germinating temperature $\left(10^{\circ} \mathrm{C}\right)$ significantly reduced $\mathrm{D}_{50}$ by a factor of $3.4(11.0 \mathrm{~d}$ to $50 \%$ germination) compared with $25{ }^{\circ} \mathrm{C}$ ( $3.2 \mathrm{~d}$ to $50 \%$ germination; Tables 1 and 2). As such, ' $\mathrm{T}-1$ ' creeping bentgrass germinated faster (i.e., lower $\mathrm{D}_{50}$ ) by achieving $50 \%$ germination in $3.2 \mathrm{~d}$ at $25{ }^{\circ} \mathrm{C}$. He et al. (2013) reported initial emergence of 4 to $5 \mathrm{~d}$ in kentucky bluegrass (Poa pratensis L.) when measured under constant temperatures between 20 to $30^{\circ} \mathrm{C}$, whereas at $10^{\circ} \mathrm{C}$ initial germination time ranged from 11 to 14 $\mathrm{d}$. When seeding in spring, cold soil temperature is often one of the major limiting factors affecting seed germination, which can significantly delay turfgrass establishment and cover during spring periods and postpone play on damaged areas under repair. Liu et al. (2001) found rough bluegrasses (Poa trivialis L.) germination at $10{ }^{\circ} \mathrm{C}$ (daytime) temperature to be significantly delayed by several days compared with $25^{\circ} \mathrm{C}$. Similarly, Hardegree (1994) reported a 2-fold higher $\mathrm{D}_{50}$ at $10{ }^{\circ} \mathrm{C}(8.7 \mathrm{~d})$ than at $25^{\circ} \mathrm{C}(4.1 \mathrm{~d})$ for sheep fescue (Festuca ovina L.) and reported most cool-season grasses required between 4 to $11 \mathrm{~d}$ longer to achieve $50 \%$ germination at $10{ }^{\circ} \mathrm{C}$. Delay of seed germination by only a few days due to cold temperatures in spring has been shown to be sufficient to affect seedling survival (Young and Evans, 1982).

Expt. 1: Priming main effects on $D_{50}$. Priming orthogonal contrast main effects (6 df) were significant $(P \leq 0.05$, Table 1$)$. Partitioning of the priming main effects into pre-planned single df contrasts indicated the contrast comparing redox $\left(\mathrm{H}_{2} \mathrm{O}_{2}\right)$ priming vs. hormone priming (ABA $+\mathrm{GA})$ and osmotic priming (GB + PEG) accounted for this statistical priming effect $(P \leq 0.01)$. Redox priming averaged $8.2 \mathrm{~d}$ to $50 \%$ germination (i.e., $\mathrm{D}_{50}$ ) and delayed germination compared with the group average for hormone and osmotic priming of $6.9 \mathrm{~d}$ (Table 2). Similarly, ABA delayed germination compared with GA by $\approx 1.1 \mathrm{~d}(P \leq 0.10)$. Hormone primer GA $\left(D_{50}=6.6 \mathrm{~d}\right)$ and osmotic primer GB $\left(D_{50}=6.3 \mathrm{~d}\right)$ were statistically equal to the control $\mathrm{D}_{50}$ average of $6.4 \mathrm{~d}$ (water primed and unprimed average) (Tables 1 and 2). All other priming treatments such as $\mathrm{ABA}$ and $\mathrm{H}_{2}$ $\mathrm{O}_{2}$ significantly delayed germination to $50 \%$ compared with the control. No significant interaction between priming treatment and temperature was observed (Table 1). Use of priming technology to accelerate seed germination rate under less favorable periods serves as an option to enhance seeding success (Jisha et al., 2013). However, such enhancement in germination rate by various priming treatments over the water primed or unprimed control were not observed in Expt. 
Table 1. Expt. 1 analysis of variance for days to $50 \%$ germination $\left(\mathrm{D}_{50}\right)$ and maximum germination $\left(\mathrm{G}_{\mathrm{max}}\right)$ derived from curve fitting of ' $\mathrm{T}-1$ ' creeping bentgrass germination as affected by two temperatures and 17 seed-priming treatments.

\begin{tabular}{|c|c|c|c|}
\hline Source of variation & $\mathrm{df}$ & $\mathrm{D}_{50}$ & $\mathrm{G}_{\max }$ \\
\hline Temperature (T): 10 vs. $25^{\circ} \mathrm{C}$ & 1 & $* * *$ & $* * *$ \\
\hline Treatment (TRT): Priming and rate & 16 & $* * *$ & NS \\
\hline Priming $(\mathrm{P})$ orthogonal contrasts & 6 & $*$ & NS \\
\hline Control (water primed + no) vs. all & 1 & NS & NS \\
\hline Water-priming vs. unprimed & 1 & NS & NS \\
\hline Hormone $^{\mathrm{z}}$ vs. osmopriming ${ }^{\mathrm{y}}$ & 1 & NS & NS \\
\hline ABA vs. GA & 1 & $\dagger$ & NS \\
\hline GB vs. PEG & 1 & NS & NS \\
\hline $\mathrm{H}_{2} \mathrm{O}_{2}$ vs. $\mathrm{ABA}+\mathrm{GA}+\mathrm{GB}+\mathrm{PEG}$ & 1 & $* *$ & NS \\
\hline Priming rate $(\mathrm{R})$ orthogonal contrasts ${ }^{\mathrm{x}}$ & 10 & $* * *$ & $*$ \\
\hline $\mathrm{ABA}_{\mathrm{L}}$ & 1 & $*$ & NS \\
\hline $\mathrm{ABA}_{\mathrm{Q}}$ & 1 & $\dagger$ & $* * *$ \\
\hline $\mathrm{GA}_{\mathrm{L}}$ & 1 & NS & * \\
\hline $\mathrm{GA}_{\mathrm{Q}}$ & 1 & NS & NS \\
\hline $\mathrm{GB}_{\mathrm{L}}^{\mathrm{2}}$ & 1 & NS & NS \\
\hline $\mathrm{GB}_{\mathrm{Q}}$ & 1 & NS & NS \\
\hline $\mathrm{H}_{2} \mathrm{O}_{2 \mathrm{~L}}$ & 1 & $* * *$ & NS \\
\hline $\mathrm{H}_{2} \mathrm{O}_{2 \mathrm{Q}}$ & 1 & $*$ & NS \\
\hline $\mathrm{PEG}_{\mathrm{L}}$ & 1 & $*$ & NS \\
\hline $\mathrm{PEG}_{\mathrm{Q}}$ & 1 & NS & NS \\
\hline $\mathrm{TRT} \times \mathrm{T}$ & 16 & NS & * \\
\hline $\mathrm{P} \times \mathrm{T}$ orthogonal contrasts & 6 & NS & $\dagger$ \\
\hline Control (water primed + no) vs. all $\times \mathrm{T}$ & 1 & NS & $*$ \\
\hline Water-priming vs. unprimed $\times \mathrm{T}$ & 1 & NS & NS \\
\hline Hormone $^{\mathrm{z}}$ vs. osmopriming ${ }^{\mathrm{y}} \times \mathrm{T}$ & 1 & NS & NS \\
\hline ABA vs. $\mathrm{GA} \times \mathrm{T}$ & 1 & NS & NS \\
\hline $\mathrm{GB}$ vs. $\mathrm{PEG} \times \mathrm{T}$ & 1 & NS & * \\
\hline $\mathrm{H}_{2} \mathrm{O}_{2}$ vs. $\mathrm{ABA}+\mathrm{GA}+\mathrm{GB}+\mathrm{PEG} \times \mathrm{T}$ & 1 & NS & NS \\
\hline $\mathrm{R} \times \mathrm{T}$ orthogonal contrasts & 10 & NS & $\dagger$ \\
\hline $\mathrm{ABA}_{\mathrm{L}} \times \mathrm{T}$ & 1 & NS & NS \\
\hline $\mathrm{ABA}_{\mathrm{Q}} \times \mathrm{T}$ & 1 & NS & NS \\
\hline $\mathrm{GA}_{\mathrm{L}} \times \mathrm{T}$ & 1 & NS & NS \\
\hline $\mathrm{GA}_{\mathrm{Q}} \times \mathrm{T}$ & 1 & NS & $*$ \\
\hline $\mathrm{GB}_{\mathrm{L}} \times \mathrm{T}$ & 1 & NS & $* * *$ \\
\hline $\mathrm{GB}_{\mathrm{Q}} \times \mathrm{T}$ & 1 & NS & NS \\
\hline $\mathrm{H}_{2} \mathrm{O}_{2 \mathrm{~L}} \times \mathrm{T}$ & 1 & NS & NS \\
\hline $\mathrm{H}_{2} \mathrm{O}_{2 \mathrm{Q}} \times \mathrm{T}$ & 1 & NS & NS \\
\hline $\mathrm{PEG}_{\mathrm{L}} \times \mathrm{T}$ & 1 & $* *$ & $\dagger$ \\
\hline $\mathrm{PEG}_{\mathrm{Q}} \times \mathrm{T}$ & 1 & NS & NS \\
\hline
\end{tabular}

${ }^{\mathrm{z}}$ Hormone treatments represent GA (gibberellic acid) and ABA (abscisic acid).

${ }^{\mathrm{y}}$ Osmopriming treatments represent GB (glycinebetaine) and PEG (polyethylene glycol).

${ }^{\mathrm{x}}$ Rates for priming treatments were partitioned as linear $(\mathrm{L})$ and quadratic $(\mathrm{Q})$ orthogonal contrasts.

$\dagger, *, * *, * * *$ Significant at $P \leq 0.10,0.05,0.01$, or 0.001 , respectively.

1 as indicated by the nonsignificant contrast: Control (water primed + no) vs. all (Table 1). This is consistent with other reports in turfgrass (Pill and Necker, 2001; Zhang et al., 2014; Zhang and Rue, 2012).

Expt. 1: Priming rate main effects on $D_{50}$. The effects of rate (linear and quadratic components) of priming were significant for ABA, $\mathrm{H}_{2} \mathrm{O}_{2}$, and PEG (Table 1). Linear and quadratic single df contrasts and the effects of rate were statistically unimportant for GA and GB and therefore their priming effects were independent of rate. Similarly, Zhang and Rue (2012) observed no rate effect when priming seed using GB at five rate levels ranging from 50 to $200 \mathrm{~mm}$. Osmotic primer PEG promoted faster germination (i.e., lower $\left.\mathrm{D}_{50}\right)$ at higher rates $\left(200\right.$ and $\left.300 \mathrm{~g} \cdot \mathrm{L}^{-1}\right)$, whereas redox primer $\mathrm{H}_{2} \mathrm{O}_{2}$ promoted lower $\mathrm{D}_{50}$ with lower rates $(0.1$ and $1 \mathrm{~mm})$ (Table 2). The hormone primer ABA promoted statistically lower $\mathrm{D}_{50}$ at the midpoint rate $(0.1 \mu \mathrm{M})$. These statistically lower $\mathrm{D}_{50}$ for $\mathrm{ABA}, \mathrm{H}_{2} \mathrm{O}_{2}$, and $\mathrm{PEG}$ germination rates did not, however, promote lower $\mathrm{D}_{50}$ compared with the water primed or unprimed controls (Table 2). However, some priming rates for $\mathrm{ABA}\left(0.2 \mu \mathrm{M}, \mathrm{D}_{50}=9.2 \mathrm{~d}\right), \mathrm{H}_{2} \mathrm{O}_{2}$ $\left(100 \mathrm{~mm}, \mathrm{D}_{50}=11.3 \mathrm{~d}\right)$, and PEG $\left(100 \mathrm{~g} \cdot \mathrm{L}^{-1}\right.$, $\mathrm{D}_{50}=8.8 \mathrm{~d}$ ) were statistically higher and therefore may potentially reduce the competitive advantage of creeping bentgrass during establishment compared with the water primed and unprimed control $\left(\mathrm{D}_{50}=6.4\right.$ and $6.3 \mathrm{~d}$, respectively) (Table 2). Delayed establishment indicated by higher $\mathrm{D}_{50}$ may lead to greater environmental stress during establishment.

Expt. 1: Priming rate $\times$ temperature interaction effects on $D_{50}$. The priming rate main effect for the osmotic primer PEG was dependent on temperature main effect (Table 1). The $\mathrm{PEG}_{\mathrm{L}} \times$ temperature interaction was the only significant $(P \leq 0.01)$ single df contrast observed (Table 1). Germination $\mathrm{D}_{50}$ at $25^{\circ} \mathrm{C}$ for PEG was $2.4,2.6$, and $3.0 \mathrm{~d}$ for 100,200 , and $300 \mathrm{~g} \cdot \mathrm{L}^{-1}$, respectively. Unlike the main effect for PEG, no statistical difference was observed between the different PEG concentrations at $25^{\circ} \mathrm{C}$. This is a major departure from the main effects for PEG discussed earlier. Effects of rate were only observed for PEG at $10^{\circ} \mathrm{C}$ where higher PEG rates (200 and $\left.300 \mathrm{~g} \cdot \mathrm{L}^{-1}\right)$ exhibited lower $\mathrm{D}_{50}$ corresponding to 9.9 and $10.1 \mathrm{~d}$ to $50 \%$ germination, respectively, which were statistically lower than the $\mathrm{D}_{50}$ of $15.3 \mathrm{~d}$ observed at $100 \mathrm{~g} \cdot \mathrm{L}^{-1}\left(\mathrm{LSD}_{0.05}=2.9\right.$ d). The water primed and unprimed control averaged $9.8 \mathrm{~d}$ to $50 \%$ germination at $10{ }^{\circ} \mathrm{C}$, and therefore the low rate of PEG promoted a significantly higher $\mathrm{D}_{50}$ (slower emergence rate) than the control. Hardegree (1994) also reported the effects of matric (water potential) priming on $\mathrm{D}_{50}$ were relatively greater at $10{ }^{\circ} \mathrm{C}$ than observed at favorable temperatures of $25{ }^{\circ} \mathrm{C}$. Other researchers have also observed the promotive effects from osmopriming were more beneficial when seeds were germinating under less favorable conditions such as low temperature (Danneberger et al., 1992).

Expt. 1: Temperature main effects on $G_{\max }$. Maximum germination percentages $\left(\mathrm{G}_{\max }\right)$ were inversely related to germination rate $\left(\mathrm{D}_{50}\right), r$ value $=-0.55(P \leq 0.001, \mathrm{n}=$ 102). Higher germinating temperatures $\left(25^{\circ} \mathrm{C}\right)$ promoted significantly higher germination percentages $(71.4 \%)$ than seeds germinating at $10{ }^{\circ} \mathrm{C}(62.0 \%)$ (Table 2). Fewer days to $50 \%$ germination (lower $\mathrm{D}_{50}$ ) and in 
Table 2. Expt. 1 fitted main effect means for days to $50 \%$ germination $\left(\mathrm{D}_{50}\right)$ and maximum germination $\left(\mathrm{G}_{\max }\right)$ as affected by two temperatures and 17 seed-priming treatments on ' $\mathrm{T}-1$ ' creeping bentgrass germination.

\begin{tabular}{|c|c|c|}
\hline Treatments & $\mathrm{D}_{50}$ & $\mathrm{G}_{\max }(\%)$ \\
\hline \multicolumn{3}{|l|}{ Temperature $\left({ }^{\circ} \mathrm{C}\right)$} \\
\hline 10 & $11.0 \mathrm{a}^{\mathrm{z}}$ & $62.0 \mathrm{~b}$ \\
\hline 25 & $3.2 \mathrm{~b}$ & $71.4 \mathrm{a}$ \\
\hline \multicolumn{3}{|l|}{ Controls } \\
\hline No water priming & 6.3 & 65.0 \\
\hline Water priming & 6.4 & 64.9 \\
\hline \multicolumn{3}{|l|}{ Priming and rate } \\
\hline \multicolumn{3}{|l|}{ ABA (abscisic acid) } \\
\hline $0.05 \mu \mathrm{M}$ & $7.2 \mathrm{ab}$ & $63.4 \mathrm{~b}$ \\
\hline $0.1 \mu \mathrm{M}$ & $6.6 \mathrm{~b}$ & $76.3 \mathrm{a}$ \\
\hline $0.2 \mu \mathrm{M}$ & $9.2 \mathrm{a}$ & $58.4 \mathrm{~b}$ \\
\hline \multicolumn{3}{|l|}{ GA (gibberellic acid) } \\
\hline $100 \mathrm{mg} \cdot \mathrm{L}^{-1}$ & 7.0 & $70.0 \mathrm{ab}$ \\
\hline $200 \mathrm{mg} \cdot \mathrm{L}^{-1}$ & 6.1 & $71.1 \mathrm{a}$ \\
\hline $300 \mathrm{mg} \cdot \mathrm{L}^{-1}$ & 6.7 & $60.9 \mathrm{~b}$ \\
\hline \multicolumn{3}{|l|}{ GB (glycinebetaine) } \\
\hline $50 \mathrm{~mm}$ & 7.0 & 65.5 \\
\hline $100 \mathrm{~mm}$ & 5.9 & 69.7 \\
\hline $150 \mathrm{~mm}$ & 6.1 & 69.1 \\
\hline \multicolumn{3}{|c|}{$\mathrm{H}_{2} \mathrm{O}_{2}$ (hydrogen peroxide) } \\
\hline $0.1 \mathrm{~mm}$ & $6.6 \mathrm{~b}$ & 66.2 \\
\hline $1 \mathrm{~mm}$ & $6.7 \mathrm{~b}$ & 70.8 \\
\hline $100 \mathrm{~mm}$ & $11.3 \mathrm{a}$ & 63.4 \\
\hline \multicolumn{3}{|c|}{ PEG (polyethylene glycol) } \\
\hline $100 \mathrm{~g} \cdot \mathrm{L}^{-1}$ & $8.8 \mathrm{a}$ & 65.5 \\
\hline $200 \mathrm{~g} \cdot \mathrm{L}^{-1}$ & $6.2 \mathrm{~b}$ & 68.0 \\
\hline $300 \mathrm{~g} \cdot \mathrm{L}^{-1}$ & $6.5 \mathrm{~b}$ & 65.9 \\
\hline \multicolumn{3}{|l|}{ Priming } \\
\hline Control & 6.4 & 65.0 \\
\hline \multicolumn{3}{|l|}{ Chemicals } \\
\hline ABA & $7.7 \mathrm{ab}$ & 66.0 \\
\hline GA & $6.6 \mathrm{bc}$ & 67.4 \\
\hline GB & $6.3 \mathrm{c}$ & 68.1 \\
\hline $\mathrm{H}_{2} \mathrm{O}_{2}$ & $8.2 \mathrm{a}$ & 66.8 \\
\hline PEG & $7.2 \mathrm{abc}$ & 66.5 \\
\hline
\end{tabular}

${ }^{\mathrm{z}}$ Numbers followed by the same letter(s) within a main effect group are not significantly different at $P \leq 0.05$ level. Statistical effects are shown only for significant main effects as indicated in Table 1 .

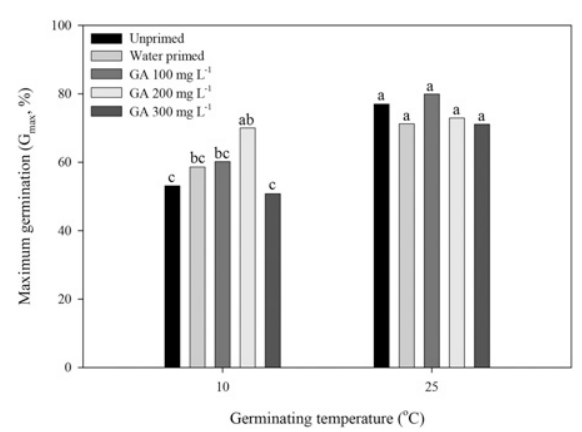

Fig. 1. Expt. 1 interactive effect for maximum germination percentage $\left(\mathrm{G}_{\max }\right)$ comparing seed priming control (water primed and unprimed) with gibberellic acid (GA) at three rates and two germinating temperatures. Means followed by the same letter(s) are not statistically different $(P \leq 0.05)$.

turn faster germination rates were generally associated with higher $\mathrm{G}_{\max }$. These two measured variables, however, explained only $30 \%$ of the total variation as covariables, suggesting that lower $\mathrm{D}_{50}$ does not necessarily equate to higher germination percentages
$\left(\mathrm{G}_{\max }\right)$. For example, no statistical difference was observed in $G_{\max }$ due to the effects of priming treatments and associated single $\mathrm{df}$ contrasts (Tables 1 and 2) even though statistical differences in $\mathrm{D}_{50}$ were observed among priming treatments in Expt. 1. The effect due to temperature explained only $37 \%$ of the total treatment variation in $\mathrm{G}_{\max }$, which was less than half of the $79 \%$ accounted for by temperature main effects on $\mathrm{D}_{50}$. The speed of germination measured as $\mathrm{D}_{50}$ was influenced more by the effects of temperature compared with temperature effects on maximum germination percentage measured as $\mathrm{G}_{\max }$. Zhang et al. (2014) also reported that daily germination percentages, the measure of the speed of germination, were more sensitive to environmental stress (drought, salinity, and temperature) than final germination percentages.

Expt. 1: Priming rate main effects on $G_{\max }$. Overall main effect of priming rate on $\mathrm{G}_{\max }$ (10 df) was significant $(P \leq 0.05$, Table 1$)$ with two single df orthogonal contrasts identified 1) ABA ( $\left.\mathrm{ABA}_{\mathrm{Q}}, P \leq 0.001\right)$ and 2) GA $\left(\mathrm{GA}_{\mathrm{L}}, P \leq 0.05\right)$, which accounted for the statistical significance in priming rate. Priming seed using ABA was most effective in increasing $\mathrm{G}_{\max }$ to $76.3 \%$ using the midpoint rate of $0.1 \mu \mathrm{M}$, which corresponded to the same ABA rate most effective in achieving faster germination rates (lower $\mathrm{D}_{50}$ ) (Table 2). Hormone primer GA at 100 and $200 \mathrm{mg} \cdot \mathrm{L}^{-1}$ was generally associated with higher $\mathrm{G}_{\max }$ $(>70 \%$ ) compared with GA priming at 300 $\mathrm{mg} \cdot \mathrm{L}^{-1}\left(\mathrm{G}_{\max }=60.9 \%\right)$ (Table 2$)$.

Expt. 1: Priming $\times$ Temperature interaction effects on $G_{\max }$. No significant statistical main effect due to priming treatment and associated contrasts were observed for $G_{\max }$. However, significant interactions were detected between temperature and priming main effects (Table 1). Two single df orthogonal (interaction) contrasts were detected for the priming $\times$ temperature interaction 1 ) Control (water primed + no) vs. all $\times$ temperature and 2) GB vs. PEG $\times$ temperature. Differences between the control (water primed + unprimed) vs. all other priming treatments (hormone + osmopriming + redox) varied with the germinating temperature $\left(10\right.$ vs. $\left.25^{\circ} \mathrm{C}\right)$. Close inspection of the interaction revealed that no difference in $\mathrm{G}_{\max }$ between the control $(74.1 \%)$ vs. priming (71.1\%, hormone + osmopriming + redox $)$ was observed at $25{ }^{\circ} \mathrm{C}$, which is consistent with the priming main effects. However, at $10^{\circ} \mathrm{C}$ seed priming (hormone + osmopriming + redox) afforded significantly better germination percentages $(62.8 \%)$ than the control $(55.9 \%)$ $\left(\mathrm{LSD}_{0.05}=6.8 \%\right)$. The effects comparing the two competing osmopriming treatments (GB vs. PEG) varied with temperature. Polyethylene glycol exhibited significantly lower $G_{\max }$ at $10{ }^{\circ} \mathrm{C}(59.8 \%)$ compared with $25{ }^{\circ} \mathrm{C}$ $(73.1 \%)\left(\operatorname{LSD}_{0.05}=6.7 \%\right)$, which is consistent with the temperature main effect. Alternatively, the $\mathrm{G}_{\max }$ for GB at the colder germinating temperature of $10^{\circ} \mathrm{C}(67.0 \%)$ that was statistically equivalent to $G_{\max }$ at the more favorable germinating temperature of $25^{\circ} \mathrm{C}$
$(69.2 \%)$, which is a major departure from temperature main effects (Tables 1 and 2). Moreover, osmopriming with GB primed seed at $10{ }^{\circ} \mathrm{C}$ promoted significantly higher $\mathrm{G}_{\max }(67.0 \%)$ than observed with PEG $(59.8 \%)$. The interactive effects of seed priming treatments (hormone + osmopriming + redox) with temperature revealed some enhancement of $\mathrm{G}_{\max }$ over the water primed and unprimed control at low germinating temperatures. These results at low germinating temperatures are consistent with previous studies in cool-season turfgrass in which germination is generally more variable at unfavorable $\left(10{ }^{\circ} \mathrm{C}\right)$ temperatures than at warm temperatures $\left(25^{\circ} \mathrm{C}\right)$ (Liu et al., 2001). These same authors reported similar $\mathrm{G}_{\max }$ averages of $\approx 56.0 \%$ to our $62.0 \%$ (Table 2 ) for the same germinating temperature of $10{ }^{\circ} \mathrm{C}$.

Expt. 1: Priming rate $\times$ temperature interaction effects on $G_{\max }$. Two significant single df contrasts were identified for priming rate $\times$ temperature interaction including 1) $\mathrm{GA}_{\mathrm{Q}} \times$ temperature $(P \leq 0.05)$ (Fig. 1) and 2$)$ $\mathrm{GB}_{\mathrm{L}} \times$ temperature $(P \leq 0.001)$ (Fig. 2$)$. Seed germinating at $10{ }^{\circ} \mathrm{C}$ primed with $\mathrm{GA}$ at 200 $\mathrm{mg} \cdot \mathrm{L}^{-1}$ promoted $\mathrm{G}_{\max }$ that was statistically equivalent to $G_{\max }$ germinating at $25^{\circ} \mathrm{C}$ (Fig. 1). Creeping bentgrass seed primed with GA using $200 \mathrm{mg} \cdot \mathrm{L}^{-1}$ concentration exhibited greater $G_{\max }$ than unprimed seed at the cold germinating temperature. Although seed priming with GA showed a statistical benefit over unprimed seed under unfavorable temperatures, no differences between GA treatments and the controls were observed at favorable germinating temperatures of $25{ }^{\circ} \mathrm{C}$ (Fig. 1). GB-treated seed primed using the lowest rate $(50 \mathrm{~mm})$ also provided higher $G_{\max }$ than the unprimed control when germinating under unfavorable temperatures $\left(10^{\circ} \mathrm{C}\right)$ (Fig. 2). Alternatively, the same $50 \mathrm{~mm}$ concentration of GB when germinating under more favorable temperatures $\left(25{ }^{\circ} \mathrm{C}\right)$ significantly inhibited $\mathrm{G}_{\max }$ compared with the unprimed control (Fig. 2). The effects of $\mathrm{GB}$ and associated positive or negative rate effects on $\mathrm{G}_{\max }$ were therefore highly dependent on the germinating temperature (Table 1). Farooq et al. (2008) reported seeds of maize (Zea mays L.) presoaked in GB at 50, 100, and 150 $\mathrm{mg} \cdot \mathrm{L}^{-1}$ enhanced the chilling tolerance during germination with the best results occurring with $100 \mathrm{mg} \cdot \mathrm{L}^{-1}$. Zhang et al. (2014) found that the effectiveness of priming with GB during seed germination of several turfgrass species was rate (concentration) dependent.

Expt. 2: Temperature main effects on $D_{50}$. Similar to Expt. 1, in Expt. 2 the effect of temperature $\left(10\right.$ vs. $\left.25^{\circ} \mathrm{C}\right)$ accounted for the majority $(98.5 \%)$ of the total treatment variation in germination rate $\left(D_{50}\right)$. Low temperature $\left(10{ }^{\circ} \mathrm{C}\right)$ reduced $\mathrm{D}_{50}$ by $5.6 \mathrm{~d}(8.1 \mathrm{~d}$ to $50 \%$ germination) compared with $25{ }^{\circ} \mathrm{C}$ ( $2.5 \mathrm{~d}$ to $50 \%$ germination; Tables 3 and 4 ). On average, Expt. 2 (5.3 d to 50\% germination) was $34 \%$ faster (lower $\mathrm{D}_{50}$ ) than Expt. 1 (7.1 $\mathrm{d}$ to $50 \%$ germination). 
Expt. 2: Priming main effects on $D_{50}$. Priming effects (6 df) were highly significant $(P \leq 0.001)$ with three single df orthogonal contrasts accounting for the variation including 1) Water-priming vs. no priming ( $P \leq$

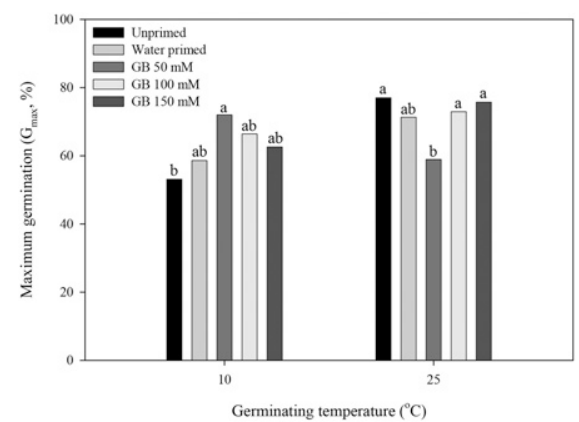

Fig. 2. Expt. 1 interactive effect for maximum germination percentage $\left(\mathrm{G}_{\max }\right)$ comparing seed priming control (water primed and unprimed) with glycinebetaine (GB) at three rates and two germinating temperatures. Means followed by the same letter(s) are not statistically different $(P \leq 0.05)$.
$0.05), 2)$ ABA vs. GA $(P \leq 0.001)$, and 3$) \mathrm{H}_{2}$ $\mathrm{O}_{2}$ vs. $\mathrm{ABA}+\mathrm{GA}+\mathrm{GB}+\mathrm{PEG}(P \leq 0.001)$. Overall, the following order from slower to faster germination rate (lower $\mathrm{D}_{50}$ ) was observed: $\mathrm{H}_{2} \mathrm{O}_{2}$ (5.6 d), ABA (5.4 d), PEG (5.3 d), GB (5.1 d), and GA (5.0 d) (Table 4). Consistent with Expt. 1, redox $\left(\mathrm{H}_{2} \mathrm{O}_{2}\right)$ priming significantly delayed germination compared with all other seed priming treatments $(\mathrm{ABA}+\mathrm{GA}+\mathrm{GB}+\mathrm{PEG})$; group average of 5.6 vs. $5.2 \mathrm{~d}$ to $50 \%$ germination, respectively. Also, hormone primer ABA significantly delayed germination $\left(\mathrm{D}_{50}=5.4 \mathrm{~d}\right)$ compared with priming seed with the hormone GA $\left(\mathrm{D}_{50}=5.0 \mathrm{~d}\right)$ (Table 4$)$. Interestingly, unlike the results reported in Expt. 1, seed primed with water $\left(\mathrm{D}_{50}=5.1 \mathrm{~d}\right)$ exhibited faster germination rate than unprimed seed $\left(\mathrm{D}_{50}=5.6 \mathrm{~d}\right)$. According to priming main effects, GA and GB priming treatments were the only treatments with statistically lower $\mathrm{D}_{50}$ and faster in germination rate than the controls $\left(\mathrm{D}_{50}=5.4 \mathrm{~d}\right.$, Table 4). The benefits of priming to achieve faster germinations with GA and GB primed seeds compared with the controls (average of unprimed + water primed) were not observed in Expt. 1.

Expt. 2: Priming rate main effects on $D_{50}$. The effects of rate (linear and quadratic components) of priming were significant for GA and $\mathrm{H}_{2} \mathrm{O}_{2}$ (Table 3). Similar to Expt. 1, redox primer $\mathrm{H}_{2} \mathrm{O}_{2}$ promoted lower $\mathrm{D}_{50}$ (faster germination rates) with lower rates of $\mathrm{H}_{2} \mathrm{O}_{2}(0.1$ and $1 \mathrm{~mm})$ compared with the highest priming rate of $100 \mathrm{~mm}$ (Table 4). Hormone primer GA optimal concentration for germination rate was the midpoint value of $200 \mathrm{mg} \cdot \mathrm{L}^{-1}$. Therefore, the quadratic component was the principal source of variation for $\mathrm{D}_{50}$ with $\mathrm{GA}$; the $\mathrm{GA}_{\mathrm{Q}}$ was highly significant $(P \leq 0.001$, Table 3$)$. Seed primed with $\mathrm{GA}$ at $200 \mathrm{mg} \cdot \mathrm{L}^{-1}$ promoted the lowest $\mathrm{D}_{50}$ (4.7 d) observed among all priming main effects (Table 4), which was statistically lower than seed primed with water $(5.2 \mathrm{~d}$, $\mathrm{LSD}_{0.05}=0.4$ ). Plants are more susceptible to environmental stress in the seedling stages especially under conditions such as low temperature (Pill and Finch-Savage, 1988). Faster establishment indicated by lower $\mathrm{D}_{50}$ with creeping bentgrass seed primed with GA

Table 3. Expt. 2 analysis of variance for days to $50 \%$ germination $\left(D_{50}\right)$ and maximum germination $\left(G_{\max }\right)$ derived from curve fitting of 'T-1' creeping bentgrass germination as affected by two temperatures and 17 seed-priming treatments.

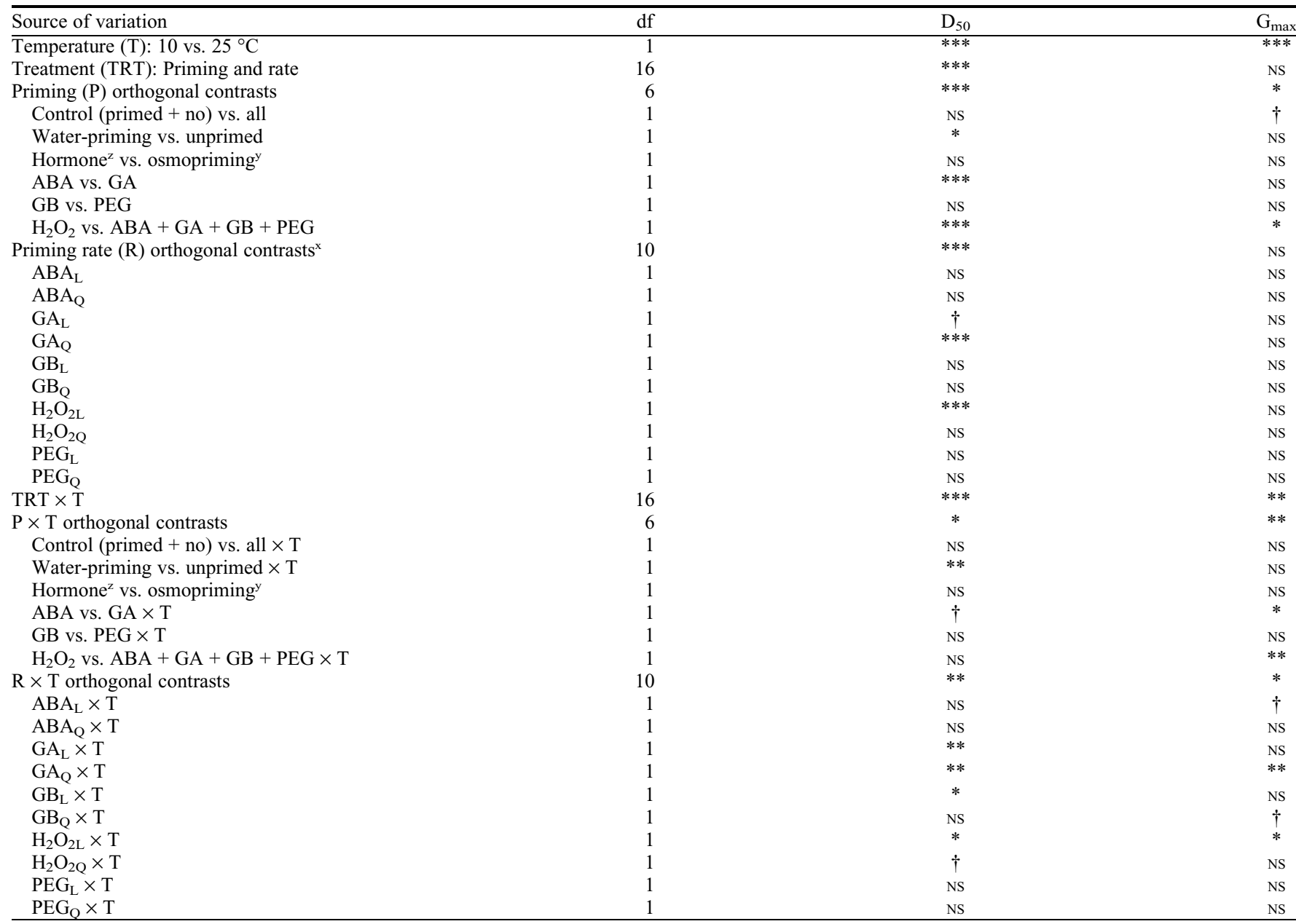

${ }^{\mathrm{Z}}$ Hormone treatments represent GA (gibberellic acid) and ABA (abscisic acid).

${ }^{\mathrm{y} O s m o p r i m i n g ~ t r e a t m e n t s ~ r e p r e s e n t ~ G B ~(g l y c i n e b e t a i n e) ~ a n d ~ P E G ~(p o l y e t h y l e n e ~ g l y c o l) . ~}$

${ }^{\mathrm{x}}$ Rates for chemical priming treatments were partitioned as linear (L) and quadratic (Q) orthogonal contrasts.

$\dagger, *, * *, * * *$ Significant at $P \leq 0.10,0.05,0.01$, or 0.001 , respectively. 
Table 4. Expt. 2 fitted main effect means for days to $50 \%$ germination $\left(D_{50}\right)$ and maximum germination $\left(\mathrm{G}_{\mathrm{max}}\right)$ as affected by two temperatures and 17 seed-priming treatments on ' $\mathrm{T}-1$ ' creeping bentgrass germination.

\begin{tabular}{|c|c|c|}
\hline Treatments & $D_{50}$ & $\mathrm{G}_{\max }(\%)$ \\
\hline \multicolumn{3}{|l|}{ Temperature $\left({ }^{\circ} \mathrm{C}\right)$} \\
\hline 10 & $8.1 \mathrm{a}^{\mathrm{z}}$ & $58.1 \mathrm{~b}$ \\
\hline 25 & $2.5 \mathrm{~b}$ & $76.5 \mathrm{a}$ \\
\hline \multicolumn{3}{|l|}{ Controls } \\
\hline No water priming & $5.6 \mathrm{a}$ & 72.1 \\
\hline Water priming & $5.1 \mathrm{~b}$ & 70.8 \\
\hline \multicolumn{3}{|l|}{ Priming and rate } \\
\hline \multicolumn{3}{|l|}{ ABA (abscisic acid) } \\
\hline $0.05 \mu \mathrm{M}$ & 5.3 & 68.1 \\
\hline $0.1 \mu \mathrm{M}$ & 5.6 & 64.8 \\
\hline $0.2 \mu \mathrm{M}$ & 5.4 & 60.2 \\
\hline \multicolumn{3}{|l|}{ GA (gibberellic acid) } \\
\hline $100 \mathrm{mg} \cdot \mathrm{L}^{-1}$ & $5.4 \mathrm{a}$ & 67.7 \\
\hline $200 \mathrm{mg} \cdot \mathrm{L}^{-1}$ & $4.7 \mathrm{~b}$ & 68.0 \\
\hline $300 \mathrm{mg} \cdot \mathrm{L}^{-1}$ & $5.1 \mathrm{a}$ & 69.2 \\
\hline \multicolumn{3}{|l|}{ GB (glycinebetaine) } \\
\hline $50 \mathrm{~mm}$ & 5.3 & 74.1 \\
\hline $100 \mathrm{~mm}$ & 5.2 & 68.5 \\
\hline $150 \mathrm{~mm}$ & 5.0 & 70.2 \\
\hline \multicolumn{3}{|c|}{$\mathrm{H}_{2} \mathrm{O}_{2}$ (hydrogen peroxide) } \\
\hline $0.1 \mathrm{~mm}$ & $5.2 \mathrm{~b}$ & 60.1 \\
\hline $1 \mathrm{~mm}$ & $5.5 \mathrm{~b}$ & 62.5 \\
\hline $100 \mathrm{~mm}$ & $6.0 \mathrm{a}$ & 64.0 \\
\hline \multicolumn{3}{|c|}{ PEG (polyethylene glycol) } \\
\hline $100 \mathrm{~g} \cdot \mathrm{L}^{-1}$ & 5.3 & 69.6 \\
\hline $200 \mathrm{~g} \cdot \mathrm{L}^{-1}$ & 5.2 & 66.8 \\
\hline $300 \mathrm{~g} \cdot \mathrm{L}^{-1}$ & 5.3 & 67.4 \\
\hline \multicolumn{3}{|l|}{ Priming } \\
\hline Control & 5.4 & 71.5 \\
\hline \multicolumn{3}{|l|}{ Chemicals } \\
\hline $\mathrm{ABA}$ & $5.4 \mathrm{ab}$ & $64.4 \mathrm{bc}$ \\
\hline GA & $5.0 \mathrm{~d}$ & $68.3 \mathrm{ab}$ \\
\hline GB & $5.1 \mathrm{~cd}$ & $70.9 \mathrm{a}$ \\
\hline $\mathrm{H}_{2} \mathrm{O}_{2}$ & $5.6 \mathrm{a}$ & $62.2 \mathrm{c}$ \\
\hline PEG & $5.3 \mathrm{bc}$ & $67.9 \mathrm{ab}$ \\
\hline
\end{tabular}

${ }^{\mathrm{z}}$ Numbers followed by the same letter(s) within a main effect group are not significantly different at $P \leq$ 0.05 level. Statistical effects are shown only for significant main effects as indicated in Table 3 .

at $200 \mathrm{mg} \cdot \mathrm{L}^{-1}$ may lead to less environmental stress during establishment.

Expt. 2: Priming $\times$ temperature interaction effects on $D_{50}$. In Expt. 1 no interaction between seed priming treatments with temperature was observed for $D_{50}$ (Table 1). Two significant single df orthogonal contrasts for interaction were observed, however, during Expt. 2 including 1) waterpriming vs. no priming $\times$ temperature $(P \leq$ $0.01)$ and 2$)$ ABA vs. GA $\times$ temperature $(P \leq$ 0.1 ) (Table 3). Although main effect means for priming treatments indicated that priming with water significantly increase the speed of germination by reducing $\mathrm{D}_{50}$ compared with the unprimed control, the effect was temperature specific. For example, at $25{ }^{\circ} \mathrm{C}$ no difference between water-primed and unprimed seed was found for $\mathrm{D}_{50}(2.4 \mathrm{vs}$. $2.5 \mathrm{~d}$, respectively. At $10{ }^{\circ} \mathrm{C}$, however, a statistically significant difference was observed between the water-primed vs. unprimed seed, which averaged 7.8 vs. $8.7 \mathrm{~d}$ to $50 \%$ germination, respectively $\left(\operatorname{LSD}_{0.05}=0.5 \mathrm{~d}\right)$. In addition, the effect of seed priming on $\mathrm{D}_{50}$ using hormone $\mathrm{ABA}$ and GA was temperature dependent with GA promoting faster germination $\left(\mathrm{D}_{50}=7.7 \mathrm{~d}\right)$ than $\mathrm{ABA}\left(\mathrm{D}_{50}=8.3 \mathrm{~d}\right)\left(\mathrm{LSD}_{0.05}=0.3 \mathrm{~d}\right)$ under less favorable germinating temperatures

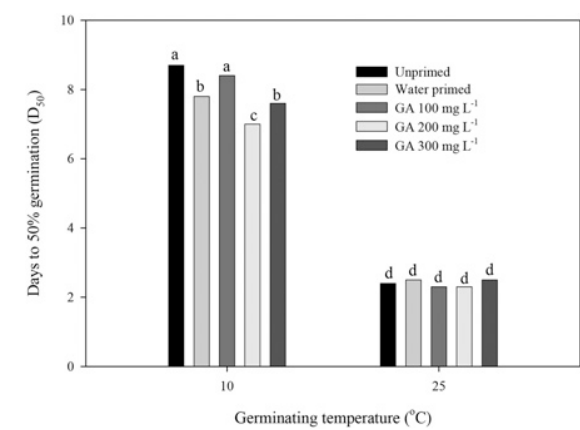

Fig. 3. Expt. 2 interactive effect for days to $50 \%$ germination $\left(\mathrm{D}_{50}\right)$ comparing three rates of gibberellic acid (GA) at two germinating temperatures. Means followed by the same letter(s) are not statistically different $(P \leq 0.05)$.

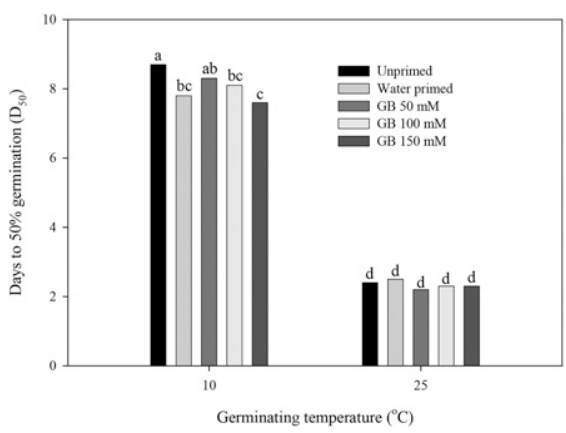

Fig. 4. Expt. 2 interactive effect for days to $50 \%$ germination $\left(D_{50}\right)$ comparing three rates of glycinebetaine (GB) at two germinating temperatures. Means followed by the same letter(s) are not statistically different $(P \leq 0.05)$.

observed according to priming rate main effects. Similarly, no difference between any GB concentrations was observed at the more favorable germinating temperatures (25 ${ }^{\circ} \mathrm{C}$ ) (Fig. 4). Redox primer $\mathrm{H}_{2} \mathrm{O}_{2}$ exhibited no effect on germination rate measured as $\mathrm{D}_{50}$ at $10{ }^{\circ} \mathrm{C}$ (Fig. 5). At $25^{\circ} \mathrm{C}$ the highest concentration $(100 \mathrm{~mm})$ of $\mathrm{H}_{2} \mathrm{O}_{2}$ significantly reduced germination vigor by increasing days to $50 \%$ germination (Fig. 5) and delaying days to germination to $50 \%$ by $\approx 1 \mathrm{~d}$ compared with all other concentrations evaluated. Seed priming with $\mathrm{H}_{2} \mathrm{O}_{2}$ has been reported to enhance the chilling tolerance of some species (Yadav et al., 2011). The level of change due to $\mathrm{H}_{2} \mathrm{O}_{2}$ is dependent on the stress, the concentration, and the length of exposure (Miller et al., 2009). In our study the highest concentration of $\mathrm{H}_{2} \mathrm{O}_{2}(100 \mathrm{mM})$ was inhibitory to creeping bentgrass seed germination vigor according to Expts. 1 and 2 (Tables 2 and 4). This was especially the case under more favorable temperatures for seed germination (Fig. 5). High levels of $\mathrm{H}_{2}$ $\mathrm{O}_{2}$ may be toxic to plant cells and damaging to photosynthesis when applied externally (Bowler and Fluhr, 2000; Sairam et al., 2002). In wheat (Triticum aestivum $\mathrm{L}$.), seeds primed with $80 \mathrm{mM} \mathrm{H}_{2} \mathrm{O}_{2}$ promoted optimal seedling growth under drought, whereas $120 \mathrm{~mm}$ inhibited seedling growth during 
germination relative to the water-primed seed (He et al., 2009). Priming efficacy can be highly rate dependent.

Expt. 2: Temperature main effects on $G_{\max }$. Results due to the effects of temperature on $\mathrm{G}_{\max }$ were consistent with Expt. 1 . Colder germinating temperatures $\left(10{ }^{\circ} \mathrm{C}\right)$ inhibited creeping bentgrass maximum germination percentage and reduced $\mathrm{G}_{\max }$ by $\approx 30 \%$ compared with $25^{\circ} \mathrm{C}$ (Tables 3 and 4 ). During Expt. 1, only a $15 \%$ reduction due to the effects of colder temperatures was observed. Germination percentages were higher under $25{ }^{\circ} \mathrm{C}$ and lower at $10{ }^{\circ} \mathrm{C}$ in Expt. 2 relative to Expt. 1. The main effect of temperature accounted for $\approx 66 \%$ of the total variation in $\mathrm{G}_{\max }$ during Expt. 2 to only $37 \%$ observed in Expt. 1, which is most likely due to the effects of the different seed lots.

Expt. 2: Priming main effects on $G_{\text {max }}$. In Expt. 1, no difference due to priming main effects $(6 \mathrm{df})$ or single df contrasts were observed (Table 1) while in Expt. 2 significant main effects due to priming treatments and orthogonal contrasts were detected (Table 3). GB primed seed promoted the highest $\mathrm{G}_{\max }(70.9 \%)$ with $\mathrm{H}_{2} \mathrm{O}_{2}(62.2 \%)$ the lowest $\mathrm{G}_{\max }$ (Table 4). According to single $\mathrm{df}$ contrasts, $\mathrm{H}_{2} \mathrm{O}_{2}$ reduced maximum germination percentage compared with all other priming treatments $(\mathrm{ABA}+\mathrm{GA}+\mathrm{GB}+$ PEG). Hormone primer ABA $\left(\mathrm{G}_{\max }=64.4 \%\right)$ and redox primer $\mathrm{H}_{2} \mathrm{O}_{2}\left(\mathrm{G}_{\max }=62.2 \%\right)$ inhibited $\mathrm{G}_{\max }$ compared with the waterprimed and unprimed seed $\left(\mathrm{G}_{\max }=71.5 \%\right.$, $\left.\mathrm{LSD}_{0.05}=6.3 \%\right)$. No seed priming treatment was better than the water-primed and unprimed control in enhancing $\mathrm{G}_{\max }$. Interactions were detected between the effects of temperature with priming main effects and associated single df contrasts (Table 3 ). Therefore, these results due to priming were dependent on temperature.

Expt. 2: Priming rate main effects on $G_{\text {max }}$. Unlike Expt. 1, no significant main effect due to the rate of priming was observed in Expt. 2 (Table 3). Any differences in Expt. 2 that were observed due to the effect of priming rate were the result of priming rate interaction with temperature, discussed next.

Expt. 2: Priming $\times$ temperature interaction effects on $G_{\text {max }}$. Priming $\times$ temperature interactive effects were significant for priming main effects ( $6 \mathrm{df}, P \leq 0.01$, Table 3 ) including two of the following single $\mathrm{df}$ contrasts 1$) \mathrm{ABA}$ vs. GA $\times$ temperature $(P$ $\leq 0.05)$ and 2) $\mathrm{H}_{2} \mathrm{O}_{2}$ vs. $\mathrm{ABA}+\mathrm{GA}+\mathrm{GB}+$ $\mathrm{PEG} \times$ temperature $(P \leq 0.01)$. According to main effects no difference in $G_{\max }$ was observed between hormone primers $\mathrm{ABA}$ and GA (Tables 3 and 4). Hormone primer $\mathrm{GA}$, however, afforded higher $\mathrm{G}_{\max }(61.3 \%)$ than $\mathrm{ABA}(50.5 \%)\left(\mathrm{LSD}_{0.05}=7.9 \%\right)$ under unfavorable germinating temperatures $\left(10{ }^{\circ} \mathrm{C}\right)$, whereas at $25^{\circ} \mathrm{C}$, no difference between the two primers was observed in $\mathrm{G}_{\max }(\mathrm{GA}=75.3 \%, \mathrm{ABA}=78.2 \%)$. Maximum germination percentage was lower following priming with $\mathrm{H}_{2} \mathrm{O}_{2}$ at $25{ }^{\circ} \mathrm{C}$ (Fig. 6) compared with all other primers (ABA + GA + GB + PEG), which is consis- tent with priming main effects (Tables 3 and 4). Alternatively at $10{ }^{\circ} \mathrm{C}$, no difference between $\mathrm{H}_{2} \mathrm{O}_{2}$ and the combined mean of all other primers was detected (Fig. 6). Additionally, no effect of temperature on $\mathrm{G}_{\max }$ was observed following priming with $\mathrm{H}_{2} \mathrm{O}_{2}$ (Fig. 6), which is a major departure from temperature main effects (Table 4). Optimal germinating temperature of $25^{\circ} \mathrm{C}$ is expected to increase $\mathrm{G}_{\max }$ compared with less favorable germinating temperature of $10{ }^{\circ} \mathrm{C}$ (Liu et al., 2001). However, the effect of $\mathrm{H}_{2} \mathrm{O}_{2}$ was especially inhibitory to germination compared with all other priming treatments under optimal germinating temperatures, which is readily apparent in Fig. 6. Furthermore, when compared with the average $G_{\max }$ of water-primed and unprimed seed at $25^{\circ} \mathrm{C}\left(\mathrm{G}_{\max }=83.4 \%\right)$, $\mathrm{H}_{2} \mathrm{O}_{2}$ significantly reduced $\mathrm{G}_{\max }$ by $30 \%$ to $64.9 \%\left(\mathrm{LSD}_{0.05}=8.9 \%\right)$.

Expt. 2: Priming rate $\times$ temperature interaction effects on $G_{\max }$. No priming rate main effect was observed, however, significant priming rate main effect by temperature interactions were detected for the following single df contrasts 1) $\mathrm{ABA}_{\mathrm{L}} \times$ temperature $(P \leq 0.1), 2) \mathrm{GA}_{\mathrm{Q}} \times$ temperature $(P \leq 0.01)$, 3) $\mathrm{GB}_{\mathrm{Q}} \times$ temperature $(P \leq 0.1)$, and 4$) \mathrm{H}_{2} \mathrm{O}_{2 \mathrm{~L}} \times$ temperature $(P \leq 0.05)$. Hormone primer $\mathrm{ABA}$ and associated rates $(0.05,0.1$, and $0.2 \mu \mathrm{M})$ had no effect on $\mathrm{G}_{\max }$ at $10{ }^{\circ} \mathrm{C}$, which ranged from 48.5 to $52.2 \%$. At favorable germinating temperatures of $25{ }^{\circ} \mathrm{C}$ the same concentrations of $\mathrm{ABA}(0.05,0.1$, and $0.2 \mu \mathrm{M})$ were significantly linear; $G_{\max }$ decreased with increasing concentrations of ABA from $85.3,81.1 \%$ to $68.2 \%$, respectively $\left(\mathrm{LSD}_{0.05}=13.7 \%\right)$. The $\mathrm{G}_{\max }$ for waterprimed seed $(84.8 \%)$ and unprimed seed $(81.8 \%)$ were significantly higher than ABA seed primed using the $0.2 \mu \mathrm{M}$ concentration at $25^{\circ} \mathrm{C}$. Therefore, hormone primer ABA significantly inhibited creeping bentgrass seed germination at the higher concentration under favorable germinating temperatures. The rate effect of hormone primer GA and osmotic primer $\mathrm{GB}$ on $\mathrm{G}_{\max }$ were quadratic and dependent on the germinating temperature. At $10{ }^{\circ} \mathrm{C}$ germinating temperature, $\mathrm{G}_{\max }$ of creeping bentgrass seed primed with GA at $200 \mathrm{mg} \cdot \mathrm{L}^{-1}$ concentration was superior to all other GA rates including water-primed and unprimed seed (Fig. 7). At $25^{\circ} \mathrm{C}$ the same GA concentration of $200 \mathrm{mg} \cdot \mathrm{L}^{-1}$ was statistically no different from other GA priming concentrations but significantly inhibited $\mathrm{G}_{\max }$ compared with water-primed and unprimed seed (Fig. 7). Differences between seed priming rates using the osmotic primer GB were only observed at $10{ }^{\circ} \mathrm{C}$. Maximum germination percentage using $\mathrm{GB}$ at $10{ }^{\circ} \mathrm{C}$ germinating temperature was highest at the lowest concentration of $50 \mathrm{~mm}$, which increased $G_{\max }$ compared with the $100 \mathrm{~mm}$ concentration and was superior to the waterprimed and unprimed seed (Fig. 8). Redox primer $\mathrm{H}_{2} \mathrm{O}_{2}$ at the highest concentration $(100 \mathrm{~mm})$ increased $\mathrm{G}_{\max }$ compared with the $0.1 \mathrm{~mm}$ concentration, whereas no differences among $\mathrm{H}_{2} \mathrm{O}_{2}$ concentrations were observed under favorable germinating tem-

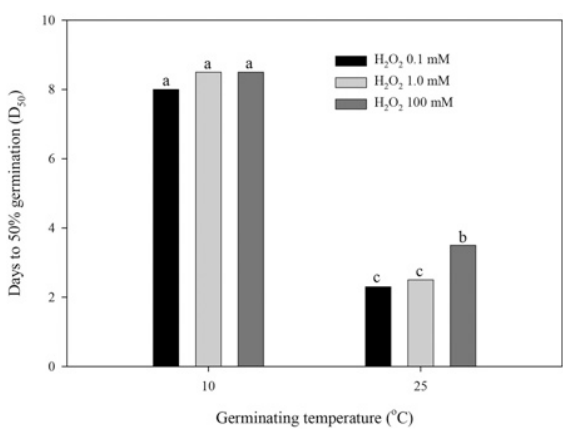

Fig. 5. Expt. 2 interactive effect for days to $50 \%$ germination $\left(\mathrm{D}_{50}\right)$ comparing three rates of redox primer $\left(\mathrm{H}_{2} \mathrm{O}_{2}\right)$ at two germinating temperatures. Means followed by the same letter(s) are not statistically different $(P \leq 0.05)$.

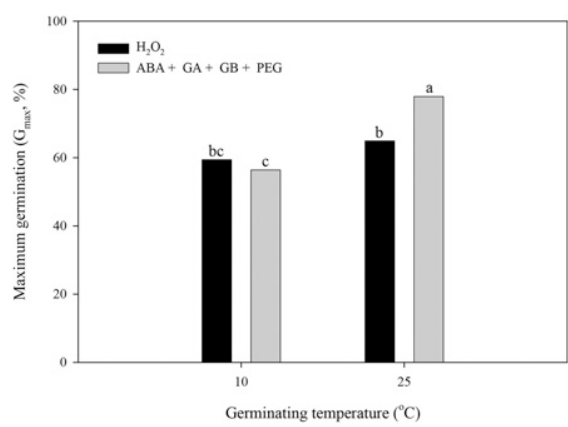

Fig. 6. Expt. 2 interactive effect for maximum germination percentage $\left(\mathrm{G}_{\max }\right)$ comparing redox seed primer $\left(\mathrm{H}_{2} \mathrm{O}_{2}\right)$ with all other priming treatments (abscisic acid, ABA; gibberellic acid, GA; glycinebetaine, GB; and polyethylene glycol, PEG) at two germinating temperatures. Means followed by the same letter(s) are not statistically different $(P \leq 0.05)$.

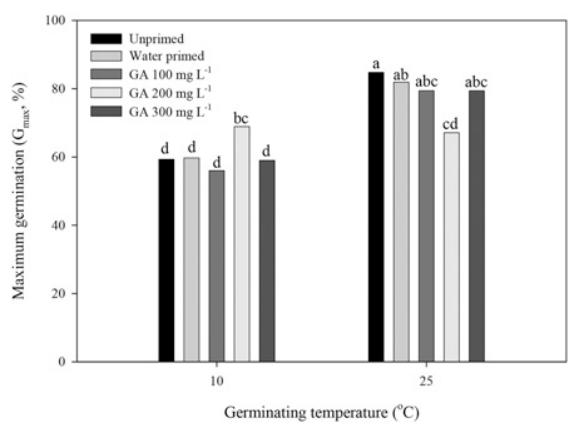

Fig. 7. Expt. 2 interactive effect for maximum germination percentage $\left(\mathrm{G}_{\max }\right)$ comparing three rates of gibberellic acid (GA) at two germinating temperatures. Means followed by the same letter(s) are not statistically different $(P \leq 0.05)$.

peratures of $25{ }^{\circ} \mathrm{C}$ (Fig. 9). Most concentrations or rates of $\mathrm{H}_{2} \mathrm{O}_{2}$ significantly inhibited germination at $25{ }^{\circ} \mathrm{C}$ compared with the unprimed and water-primed seed (Fig. 9). Interestingly, $\mathrm{G}_{\max }$ in response to increase concentrations of $\mathrm{H}_{2} \mathrm{O}_{2}$ were linear $\left(\mathrm{H}_{2} \mathrm{O}_{2 \mathrm{~L}}\right.$, Table 3$)$ with a positive trend at 


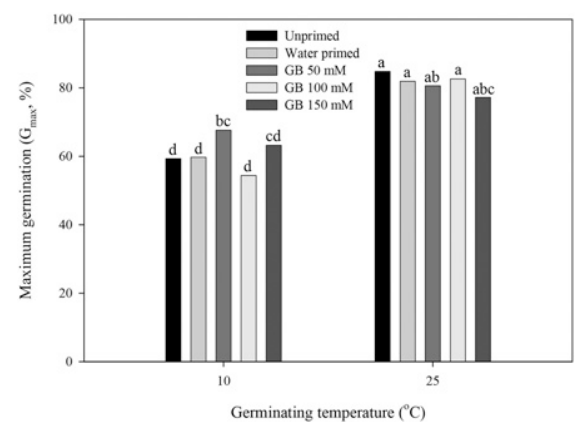

Fig. 8. Expt. 2 interactive effect for maximum germination percentage $\left(\mathrm{G}_{\max }\right)$ comparing three rates of glycinebetaine $(\mathrm{GB})$ at two germinating temperatures. Means followed by the same letter(s) are not statistically different $(P \leq 0.05)$.

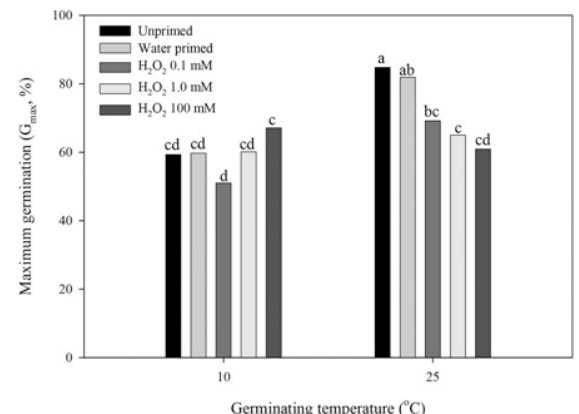

Fig. 9. Expt. 2 interactive effect for maximum germination percentage $\left(\mathrm{G}_{\max }\right)$ comparing three rates of redox primer $\left(\mathrm{H}_{2} \mathrm{O}_{2}\right)$ at two germinating temperatures. Means followed by the same letter(s) are not statistically different $(P \leq 0.05)$.

$10{ }^{\circ} \mathrm{C}$ and negative trend in response to $\mathrm{H}_{2} \mathrm{O}_{2}$ at $25{ }^{\circ} \mathrm{C}$ (Fig. 9). Results from seed priming with GB (Fig. 2) were similar to priming with $\mathrm{H}_{2} \mathrm{O}_{2}$ (Fig. 9) with $\mathrm{G}_{\max }$ exhibiting positive and negative trends in response to increasing concentrations of GB at unfavorable and favorable germinating temperatures, respectively.

The interactive effect between temperature and priming rate for $\mathrm{GB}$ (Fig. 2) and $\mathrm{H}_{2} \mathrm{O}_{2}$ (Fig. 9) are problematic from a practical perspective because of their competing effects that increase germination at $10{ }^{\circ} \mathrm{C}$ while inhibiting germination at $25{ }^{\circ} \mathrm{C}$. Cool-season grasses at planting may be exposed to a range of soil temperatures during establishment. Seed priming treatments and their rates or concentrations to be effective should not retard maximum germination percentage or delay the speed of germination by increasing $\mathrm{D}_{50}$ relative to unprimed seed at either unfavorable $\left(10^{\circ} \mathrm{C}\right)$ or favorable $\left(25^{\circ} \mathrm{C}\right)$ germinating temperatures. Reseeding of cool-season grasses in the spring in northern regions following winter injuries is necessary under suboptimal conditions such as low soil temperature. Germination enhancement (i.e., higher $\mathrm{G}_{\max }$ ) and stimulating early emergence (i.e., lower $\mathrm{D}_{50}$ ) are usually observed under suboptimal temperatures (Hardegree, 1994; Heydecker et al., 1975). Both of these seed germination characteristics $\left(G_{\max }\right.$ and $\left.D_{50}\right)$ contribute to the success in the establishment of new turf stands (Newell and Bladau, 1993).

Priming creeping bentgrass seed using redox primer $\mathrm{H}_{2} \mathrm{O}_{2}$ consistently increased $\mathrm{D}_{50}$ in Expts. 1 and 2 when compared with seed primed with hormone and osmotic primers (Tables 2 and 4). Priming creeping bentgrass seed using higher concentrations of $\mathrm{H}_{2} \mathrm{O}_{2}(100 \mu \mathrm{M})$ may be especially inhibitory to stimulating faster emergence under warm and more favorable germinating temperatures (Fig. 5) and in achieving adequate germination (Fig. 9). High levels of $\mathrm{H}_{2} \mathrm{O}_{2}$ may result in toxicity to cellular membranes causing damage to plant cells (Sairam et al., 2002), which in turn may explain the inhibitory effects on germination observed in our study. Similarly, Wang et al. (2014) reported presoaking kentucky bluegrass seed with $0.3 \% \mathrm{H}_{2} \mathrm{O}_{2}$ had negative effects on seed germination and seedling growth. Priming bluegrass seed with $\mathrm{H}_{2} \mathrm{O}_{2}$ was not recommended by these authors.

Overall Summary of Expts. 1 and 2. Results summarized in Tables 1-4 indicate significant variability in main effects and interaction observed between Expts. 1 and 2 (i.e., different seed lots of ' $\mathrm{T}-1$ '). In addition, interactions between primers and associated concentrations with temperature were observed. The significance of the interaction between temperature with treatments (primers and priming rates) accounted for more of the variation in $G_{\max }$ than treatment main effects indicated by the partitioning of $\mathrm{G}_{\max } 16 \mathrm{df}$ into single df orthogonal contrasts. For example, partitioning $\mathrm{G}_{\max }$ revealed 10 significant interactions to only 4 significant main effects when combined across Expt. 1 (Table 1) and Expt. 2 (Table 3). Identifying consistent seed priming treatments that improve germination by increasing $G_{\max }$ and/or lowering $D_{50}$ relative to the unprimed control are problematic because of the competing (negative and positive) effects observed through interaction with germinating temperatures. Interactions among turfgrass species, temperature, and priming rate have been reported in previous seed priming studies (Zhang et al., 2014). Inconsistent results as indicated by the numerous interactions observed in our study suggest that seed priming efficacy is dependent on numerous factors in addition to seed lots, such as the priming agent, their rates, and the stress under evaluation (Iqbal and Ashraf, 2005).

Table 5 summarizes the effects relative to the unprimed control for all primers and their concentrations that were observed in Expts. 1 and 2 at the two germinating temperatures $\left(10\right.$ and $\left.25{ }^{\circ} \mathrm{C}\right)$. Seed primed with distilled water promoted earlier emergence (lower $\left.\mathrm{D}_{50}\right)$ than unprimed seed at unfavorable germinating temperatures $\left(10^{\circ} \mathrm{C}\right)$ in Expt. 1 with no adverse effects observed (i.e., neither significantly lower $G_{\max }$ nor higher $D_{50}$ ) during Expts. 1 and 2. Creeping bentgrass seed primed with the hormone $\mathrm{ABA}$ at 0.05 $\mu \mathrm{M}$ concentration promoted faster emergence (lower $\mathrm{D}_{50}$ ) than the unprimed control under cold germinating conditions (Expt. 2) without promoting any adverse effects. In addition, seed primed with $\mathrm{ABA}$ at $0.1 \mu \mathrm{M}$ concentration promoted higher $G_{\max }$ than the unprimed control at $10{ }^{\circ} \mathrm{C}$ (Expt. 1) without causing any adverse effects on germination relative to unprimed seed. The highest concentration of ABA $(0.2 \mu \mathrm{M})$ exhibited competing effects on $\mathrm{D}_{50}$ and inhibited $G_{\max }$ relative to the unprimed seed under favorable germinating temperatures (Expt. 2). These results suggest that seed primed with $\mathrm{ABA}$ at 0.05 and $0.01 \mu \mathrm{M}$ concentrations were most effective for enhancing germination compared with unprimed seed. Hormone primer GA using the $100 \mathrm{mg} \cdot \mathrm{L}^{-1}$ concentration exhibited no effect and therefore provided no adverse or beneficial effects on germination relative to unprimed seed. Priming seed using GA at the $200 \mathrm{mg} \cdot \mathrm{L}^{-1}$ concentration promoted competing effects on $G_{\max }$, which varied with germinating temperatures. Gibberellic acid at the highest concentration of $300 \mathrm{mg} \cdot \mathrm{L}^{-1}$ promoted earlier emergence (lower $D_{50}$ ) than the unprimed control at $10{ }^{\circ} \mathrm{C}$ (Expt. 2) with no adverse effects observed on germination. As such, priming creeping bentgrass seed with GA using $300 \mathrm{mg} \cdot \mathrm{L}^{-1}$ is an effective option for seed priming to achieve faster emergence. Osmotic primer GB enhanced germination relative to unprimed seed at all concentrations $(50,100,150 \mathrm{~mm})$ tested by promoting either higher $\mathrm{G}_{\max }$ (Expt. 1) or lower $\mathrm{D}_{50}$ (Expt. 2) under unfavorable germinating temperatures of $10{ }^{\circ} \mathrm{C}$. No adverse effects were observed on germination of creeping bentgrass seed using GB. Similarly, osmotic primer PEG at 200 and $300 \mathrm{~g} \cdot \mathrm{L}^{-1}$ promoted faster emergence by lowering $\mathrm{D}_{50}$ (Expt. 2) relative to unprimed seed under cold germinating temperatures with no adverse effects observed. Priming with PEG at $100 \mathrm{~g} \cdot \mathrm{L}^{-1}$ was associated with competing effects on $\mathrm{D}_{50}$ (Expts. 1 and 2) at $10{ }^{\circ} \mathrm{C}$. Redox primer $\mathrm{H}_{2}$ $\mathrm{O}_{2}$ promoted competing effects and/or adverse effects on $G_{\max }$ and $D_{50}$ relative to unprimed seed at all concentrations and germinating temperatures. Similar to the conclusion of Wang et al. (2014), the use of $\mathrm{H}_{2} \mathrm{O}_{2}$ under our test concentrations provided negative results by inhibiting germination measured as lower $G_{\max }$ and/or higher $D_{50}$ relative to unprimed seed.

In summary, of overall seed priming effectiveness relative to unprimed seed (Table 5), the potential for various primers to enhance germination as either higher $G_{\max }$ and/or lower $D_{50}$ were as follow: osmotic primers were most effective (GB and PEG, 5 of 6 priming-rate combinations, Table 5) followed by hormone primers (ABA and GA, 3 of 6 priming-rate combinations, Table 5) with redox primers least effective ( 0 of 3 priming-rate combinations, Table 5). Any enhancement of creeping bentgrass seed germination using hormone and osmotic primers and their appropriate rates were only detected 
Table 5. Summary of Expt. 1 and Expt. 2 indicating the statistical effect on days to $50 \%$ germination $\left(D_{50}\right)$ and maximum germination percentage $\left(G_{\text {max }}\right)$ following germination at two temperatures. Various seed primers and associated concentrations are compared relative to unprimed creeping bentgrass seed.

\begin{tabular}{|c|c|c|c|c|c|c|c|c|}
\hline \multirow[b]{3}{*}{ Primers and concentrations } & \multicolumn{4}{|c|}{ Expt. 1} & \multicolumn{4}{|c|}{ Expt. 2} \\
\hline & \multicolumn{2}{|c|}{$\mathrm{D}_{50}$} & \multicolumn{2}{|c|}{$\mathrm{G}_{\max }$} & \multicolumn{2}{|c|}{$\mathrm{D}_{50}$} & \multicolumn{2}{|c|}{$\mathrm{G}_{\max }$} \\
\hline & $10^{\circ} \mathrm{C}$ & $25^{\circ} \mathrm{C}$ & $10^{\circ} \mathrm{C}$ & $25^{\circ} \mathrm{C}$ & $10^{\circ} \mathrm{C}$ & $25^{\circ} \mathrm{C}$ & $10^{\circ} \mathrm{C}$ & $25^{\circ} \mathrm{C}$ \\
\hline Water primed & $0^{z}$ & 0 & 0 & 0 & - & 0 & 0 & 0 \\
\hline \multicolumn{9}{|l|}{ ABA (abscisic acid) } \\
\hline $0.05 \mu \mathrm{M}$ & 0 & 0 & 0 & 0 & - & 0 & 0 & 0 \\
\hline $0.1 \mu \mathrm{M}$ & 0 & 0 & + & 0 & 0 & 0 & 0 & 0 \\
\hline $0.2 \mu \mathrm{M}$ & + & + & 0 & 0 & - & 0 & 0 & - \\
\hline \multicolumn{9}{|l|}{ GA (gibberellic acid) } \\
\hline $100 \mathrm{mg} \cdot \mathrm{L}^{-1}$ & 0 & 0 & 0 & 0 & 0 & 0 & 0 & 0 \\
\hline $200 \mathrm{mg} \cdot \mathrm{L}^{-1}$ & 0 & 0 & + & 0 & - & 0 & 0 & - \\
\hline $300 \mathrm{mg} \cdot \mathrm{L}^{-1}$ & 0 & 0 & 0 & 0 & - & 0 & 0 & 0 \\
\hline \multicolumn{9}{|l|}{ GB (glycinebetaine) } \\
\hline $50 \mathrm{~mm}$ & 0 & 0 & + & 0 & 0 & 0 & 0 & 0 \\
\hline $100 \mathrm{~mm}$ & 0 & 0 & + & 0 & - & 0 & 0 & 0 \\
\hline $150 \mathrm{~mm}$ & 0 & 0 & 0 & 0 & - & 0 & 0 & 0 \\
\hline \multicolumn{9}{|l|}{$\mathrm{H}_{2} \mathrm{O}_{2}$ (hydrogen peroxide) } \\
\hline $0.1 \mathrm{~mm}$ & 0 & 0 & 0 & 0 & - & 0 & 0 & - \\
\hline $1 \mathrm{~mm}$ & 0 & 0 & + & 0 & 0 & 0 & 0 & - \\
\hline $100 \mathrm{~mm}$ & + & + & 0 & 0 & 0 & + & 0 & - \\
\hline \multicolumn{9}{|l|}{ PEG (polyethylene glycol) } \\
\hline $100 \mathrm{~g} \cdot \mathrm{L}^{-1}$ & + & 0 & 0 & 0 & - & 0 & 0 & 0 \\
\hline $200 \mathrm{~g} \cdot \mathrm{L}^{-1}$ & 0 & 0 & 0 & 0 & - & 0 & 0 & 0 \\
\hline $300 \mathrm{~g} \cdot \mathrm{L}^{-1}$ & 0 & 0 & 0 & 0 & - & 0 & 0 & 0 \\
\hline
\end{tabular}

${ }^{\mathrm{z}}$ Coding indicates statistical difference $(P \leq 0.05$ level) relative to unprimed (control) seed where " 0 " indicates no difference from the control; "+" indicates significantly higher from the control; “-” indicates significantly lower from the control.

under unfavorable germinating temperatures of $10{ }^{\circ} \mathrm{C}$. Germination enhancement with hormone and osmotic primers were principally the result of faster emergence due to lower $\mathrm{D}_{50}$. These results suggest that hormone and osmotic primers can benefit germination under cold (unfavorable) conditions typical of early spring establishment in northern regions. However, hormone and osmotic primers may not necessarily enhance germination under warmer or near optimal germinating temperatures of $25{ }^{\circ} \mathrm{C}$. Creeping bentgrass seed primed with water also offered faster emergence (lower $D_{50}$ ) than unprimed seed under low temperature with no enhancement of maximum germination percentage (i.e., higher $\mathrm{G}_{\max }$ ). Seed primed with GB using the $100 \mathrm{~mm}$ concentration was the only primer and concentration to enhance germination under low temperature by increasing both $\mathrm{G}_{\max }$ and early emergence (i.e., lower $\mathrm{D}_{50}$ ) compared with unprimed seed. Investigations into the interactive effects of different hormone-osmotic-redox combinations and associated rates under different germinating temperatures and field conditions are needed.

\section{Literature Cited}

Bodsworth, S. and J.D. Bewley. 1981. Osmotic priming of seeds of crop species with polyethylene glycol as a means of enhancing early and synchronous germination at cool temperatures. Can. J. Bot. 59:672-676.

Bowler, C. and R. Fluhr. 2000. The role of calcium and activated oxygens as signals for controlling cross-tolerance. Trends Plant Sci. 5:241-246.

Danneberger, T.K., M.B. McDonald, C.A. Geron, and P. Kumari. 1992. Rate of germination and seedling growth of perennial ryegrass seed following osmoconditioning. HortScience 27:28-30.

Farooq, M., T. Aziz, M. Hussain, H. Rehman, K. Jabran, and M.B. Khan. 2008. Glycinebetaine improves chilling tolerance in hybrid maize. J. Agron. Crop Sci. 194(2):152-160.

Gao, Y., P.C. Bonham-Smith, and L.V. Gusta. 2002. The role of peroxiredoxin antioxidant and calmodulin in ABA-primed seeds of Brassica napus exposed to abiotic stresses during germination. J. Plant Physiol. 159(9):951-958.

Green, T.O., E.C. Chestnut, J.N. Rogers, III, and J.R. Crum. 2018. Effects of creeping bentgrass seeding rates and traffic on putting green establishment: A conservative seeding rate can result in cost-effective and speedy green establishment. Golf Course Manage. 86(1):106-108, 110.

Hardegree, S.P. 1994. Matric priming increases germination rate of Great Basin native perennial grasses. Agron. J. 86(2):289-293.

Heydecker, W.J., J. Higgens, and Y.J. Turner. 1975. Invigorating of seeds? Seed Sci. Technol. 3:881-888

He, L., Z. Gao, and R. Li. 2009. Pretreatment of seed with $\mathrm{H}_{2} \mathrm{O}_{2}$ enhances drought tolerance of wheat (Triticum aestivum L.) seedlings. Afr. J. Biotechnol. 8:6151-6157.

He, J.Y., J.T. Wang, X.M. Bai, Q. Dong, and Y.W. Lu. 2013. Effects of temperature on seed germination characteristics of eight wild $\mathrm{Poa}$ germplasm. Pratacultural Sci. 30(3):383-389.

Iqbal, M. and M. Ashraf. 2005. Changes in growth, photosynthetic capacity and ionic relations in spring wheat (Triticum aestivum L.) due to presowing seed treatment with polyamines. Plant Growth Regulat. 46:19-30.

Jisha, K., C. Vijayakumari, and K. Puthur. 2013. Seed priming for abiotic stress tolerance: An overview. Acta Physiol. Plant. 35:1381-1396.

Knypl, J.S. and A.A. Khan. 1981. Osmoconditioning of soybean seed to improve performance at suboptimal temperatures. Agron. J. 73:112116.

Larsen, S.U., C. Andreasen, and P. Kristoffersen. 2004. Differential sowing time of turfgrass species affects the establishment of mixtures. Crop Sci. 44:1315-1322.

Larsen, S.U. and B.M. Bibby. 2004. Use of germination curves to describe variation in germination characteristics in three turfgrass species. Crop Sci. 44:891-899.
Liu, C. J. J., S.B. Camberato, and MartinTurner, A.V. 2001. Rough bluegrass germination varies with temperature and cultivar/seed lot. HortScience 36:153-156.

McGinnies, W.J. 1960. Effects of moisture stress and temperature on germination of six range grasses. Agron. J. 52:159-162.

Miller, G., N. Suzuki, S. Ciftci-Yilmaz, and R. Mittler. 2009. Reactive oxygen species homeostasis and signaling during drought and salinity stresses. Plant Cell Environ. 33:453-467.

Murray, G.A. 1990. Priming sweet corn seed to improve emergence under cool conditions. HortScience 25:231-234.

Murphy, J.A., H. Samaranayake, T.J. Lawson, J.A Honig, and S. Hart. 2005. Seeding date and cultivars impact on establishment of bentgrass in soil containing annual bluegrass seed. Int. Turfgrass Soc. Res. 10:410-415.

Newell, A.J. and N.K. Bladau. 1993. Variation in total germination, rate of germination and seed weight among cultivars of Poa pratensis. J. Sports Turf Res. Inst. 69:83-89.

Pill, W.G. 1994. Low water potential presowing germination treatments to improve seed quality, p. 319-359. In: A.S. Basra (ed.). Seed quality: Basic mechanisms and agricultural implications. Haworth Press, Binghampton, NY.

Pill, W.G. and W.E. Finch-Savage. 1988. Effects of combing priming and plant growth regulator treatments on the synchronization of carrot seed germination. Ann. Appl. Biol. 114:383389.

Pill, W.G. and A.D. Necker. 2001. The effects of seed treatments on germination and establishment of Kentucky bluegrass (Poa pratensis L.). Seed Sci. Technol. 29(1):6572.

Sairam, R.K., K.V. Rao, and G.C. Srivastava. 2002. Differential response of wheat genotypes to long term salinity stress in relation to oxidative stress, antioxidant activity and osmolyte concentration. Plant Sci. 163:10371046.

Snapp, S., R. Price, and M. Morton. 2008. Seed priming of winter annual cover crops improves 
germination and emergence. Agron. J. 100:1506-1510.

Yadav, P.V., M. Kumari, and Z. Ahmed. 2011. Seed priming mediated germination improvement and tolerance to subsequent exposure to cold and salt stress in capsicum. Res. J. Seed Sci. 4:125-136.

Yamamoto, I., A.J. Turgeon, and J.M. Duich. 1997a. Field emergence of solid matrix primed turfgrasses. Crop Sci. 37:220-225.

Yamamoto, I., A.J. Turgeon, and J.M. Duich. 1997b. Seedling emergence and growth of solid matrix primed Kentucky bluegrass seed. Crop Sci. 37:225-229.

Young, J.A. and R.A. Evans. 1982. Temperature profiles of cool season grasses. ARR-W-27. USDA-ARS, Western Region, Oakland, CA.

Wang, H.J., Z.F. Chen, Y. Zhang, Y.Q. Yang, S.Z $\mathrm{Du}$, and T. Guo. 2014. Influence of soaking times and agents on seed germination of $\mathrm{Poa}$ pratensis. Pratacultural Sci. 31(11):2095-2104.

Wright, D.L., R.E. Blazer, and J.M. Woodruff 1978. Seedling emergence as related to temperature and moisture tension. Agron. J. 70:709-712.

Zhang, Q. and K. Rue. 2012. Glycinebetaine seed priming improved osmotic and salinity tolerance in turfgrass. HortScience 47:11711174.

Zhang, Q., K. Rue, and J. Mueller. 2014. The effect of glycinebetaine priming on seed germination of six turfgrass species under drought, salinity, or temperature stress. HortScience 49:1454 1460. 